\title{
Reduced glutathione and acetylcholinesterase expressions in Perna indica exposed to trivalent arsenic
}

\author{
J. S. I. Rajkumar \\ Department of Advanced Zoology and Biotechnology, Loyola College, Chennai 600 034, Tamilnadu, India \\ Email: jsirajkumar@gmail.com
}

\begin{abstract}
In the present study Indian brown mussel, Perna indica was exposed to $20,40,80,160$ and $320 \mathrm{ppb}(\mu \mathrm{g} / \mathrm{l})$ arsenic concentrations under short-term chronic toxicity bioassay (14 days) for the assessment of reduced glutathione and acetylcholinesterase as potential biochemical biomarkers in arsenic pollution. A higher level of reduced glutathione (GSH) and increased acetylcholinesterase (AchE) activity was expressed when compared to control in 160 and $320 \mathrm{ppb}$ arsenic concentration. The found values were significant at $\mathrm{P}<0.01$. The values of total protein were significantly lower $(\mathrm{P}<0.05)$ in all the exposed concentration when compared with control. This study suggests that metabolites and antioxidant enzymes activity was affected by heavy metal exposures and strongly have the potential as indicators of heavy metal contamination and arsenic in specific. Hence, the determination of oxidative stress biomarkers in Perna indica may serve as a convenient approach during pollution biomonitoring programme.
\end{abstract}

Keywords: Arsenic, green mussel, oxidative stress, reactive oxygen species, pollution

\section{Introduction}

Even at low levels, heavy metals are capable of exerting considerable biological effects. Heavy metals at cellular level are often involved in oxidative stress, which results in the production of Reactive oxygen species (ROS) [1]. Alternations in active oxygen metabolism caused by contaminants are modulated by antioxidant enzyme activities, which can be utilized as potential biomarker to detect possible sub-lethal effects of heavy metal pollution [2]. Accumulation of excess heavy metal concentrations in tissue levels inhibits the activity of antioxidant enzymes, thereby producing Reactive oxygen species (ROS). ROS, such as superoxide radicals, hydrogen peroxide and hydroxyl radicals are continuously formed and these toxic forms of activated oxygen react with cellular components resulting in oxidation of protein, oxidative damage to DNA and lipid peroxidation and leads to cell death [3]. To prevent oxidation-induced cellular damage, organisms adapt for effective antioxidation systems involving reduced glutathione (GSH) and certain antioxidant enzymes including free radical scavenging enzymes $[4,5]$.

Alterations in the activity of antioxidant enzymes and other biochemical biomarkers are the promising and potential tools for aquatic toxicological research in heavy metal pollution $[6,7]$. Heavy metal pollution in the aquatic environment is a growing concern and, more importantly, pollution of the estuarine ecosystem is alarming. Marine bivalves such as oysters and mussels were widely used as biological indicators of contamination in the monitoring heavy metal pollution [8]. Indian brown mussel, Perna indica is an important marine bivalve resource due to their dietary and medicinal properties [9]. Mussels are commercially valuable species and cultivated on large scale along with coastal areas. They are very important for marine ecology and for human diet, since they are an important source of nutrients. Consumption of these bivalve molluscs provides an inexpensive source of protein with a high biological value, essential minerals and vitamins $[9,10]$. Different biochemical biomarkers have been successfully implemented in marine organisms in the recent decades. These biomarkers have been applied to the analysis of both pollution impacts in water courses and toxicity risk assessment of specific contaminants, both isolated and in combination [4]. In the present study, Perna indica, Indian brown mussel was exposed to arsenic in short-term chronic toxicity bioassay (Static renewal-14 days) to study the alterations in protein, reduced glutathione (GSH) and acetylcholinesterase (AChE). 


\section{Materials and methods}

Juvenile Perna indica $(1.7 \pm 0.4 \mathrm{~cm}$ in length and $0.38 \pm 0.15 \mathrm{~g})$ were collected from Kadiyapatanam coast, Kanyakumari district and transported to the laboratory in air filled plastic bags and acclimatized in glass aquaria with aerated natural filtered seawater for a period of 8 days at 29 PSU salinity, temperature of $28 \pm 1{ }^{\circ} \mathrm{C}$, dissolved oxygen of $5.5 \mathrm{mg} / \mathrm{l}$ and $\mathrm{pH}$ of 8.06. Stock solutions of arsenic was prepared with arsenic trioxide $\left(\mathrm{As}_{2} \mathrm{O}_{3}\right)$ in deionized (double distilled) water (Milli-Q). Fresh stock solutions were prepared daily. These solutions were serially diluted to get the experimental concentration for the toxicity test. The experimental method includes static renewal (24-hour renewal) test [11]. Five concentrations $(20,40,80,160$ and $320 \mu \mathrm{g} / \mathrm{l}(\mathrm{ppb}))$ in a geometric series including control were prepared for the test for 13 days in chronic toxicity test in triplicate. Toxicant and seawater were replaced on daily basis. Test animals were fed three times during the test (Chlorella). Maximum-allowable control mortality was 20 per cent for the short-term chronic toxicity test [6]. The tissue samples of survived test animals were pooled and made in duplicates at the end of the chronic toxicity test. For the biochemical studies, $1 \mathrm{~g}$ tissue was homogenized in chilled $\left(4^{\circ} \mathrm{C}\right)$ pestle and mortar with $5 \mathrm{ml}$ homogenization buffer $(0.25 \mathrm{M}$ sucrose, $10 \mathrm{mM}$ Tris, $1 \mathrm{mM}$ EDTA, and $\mathrm{pH} 7.4)$ and centrifuged at 5,000 rpm for 15 minutes at $4^{\circ} \mathrm{C}$. The resulting supernatant was the homogenate, which was used for various biochemical assays.

\subsection{Reduced Glutathione (GSH)}

The reduced glutathione (GSH) was measured at $412 \mathrm{~nm}$ using 5, 5-dithiobis-(2-nitrobenzoic acid) (DTNB) reagent [11]. The values were expressed as $\mu \mathrm{mol}$ of GSH oxidized/mg protein.

\subsection{Acetylcholinesterase Activity (AChE)}

Acetylcholinesterase activity (AChE) activity was determined using Ellman's reagent, DTNB (5, 5'-dithio-bis (2nitrobenzoic acid); $0.5 \mathrm{mM}$ ) and acetylthiocholine iodide (ACTI) as substrate [12]. The rate of change of absorbance at $412 \mathrm{~nm}$ was recorded over 1.5 minutes at $25^{\circ} \mathrm{C}$. The protein concentration of each of the sample extract was determined measured at $750 \mathrm{~nm}$ in UV-Spectrophotometer [13]. One-way ANOVA (Dunnetts Procedure-Comparison with Control) was performed with the mercury concentrations and biochemical parameters and significance were derived using GraphPad Prism [14].

\section{Results and discussion}

Perna indica exposed to arsenic showed changes in metabolites and antioxidant enzymes. The total level of protein significantly decreased with increase in concentration at $\mathrm{P}<0.001$ (Fig. 1.). Similarly, acetylcholinesterase activity also significantly decreased significantly $(\mathrm{P}<0.001)$ (Fig. 2.). Alterations in the reduced glutathione was observed in 160 and $320 \mu \mathrm{g} / \mathrm{l}$ of arsenic, where the values were found to be significant at $\mathrm{P}<0.05$ (Fig. 3.). In the present study AchE and GSH were observed to be the promising biomarkers in biochemical studies in arsenic pollution. Evidence suggests that biochemical metabolites increased due to metal exposure in bivalve, the mussel Perna perna [15]. These results are comparable to the study, where antioxidant enzyme activity increases at sites contaminated with metals [16]. Perna indica exposed to cadmium, copper, lead and zinc concentrations under chronic toxicity showed significant differences in antioxidant enzyme activity [17]. Elevated reduced glutathione (GSH) activity was observed in mollusks exposed to petrochemical products [16]. Increased GST activity exposed to zinc and copper suggests that higher pollutant stress may have induced GST expression in order to protect tissues from xenobiotic damage [18].

Low GSH levels in mussels indicated utilization of antioxidants for detoxification processes [19], wherein the present study resulted in higher levels of GSH. Similar responses of decreased GSH level have been shown in the mussel Perna perna, as an indicator of oxidative stress [20]. Seasonal alterations in the antioxidant enzyme activities were measured in the digestive gland of the brown mussel P.perna [15]. The effects of trace metals on antioxidant defence enzymes are more evident when different species are compared. Trace metals seem to influence directly on the antioxidant defence enzyme due to biological factors, which regulate fluctuations of defenses [21].

The results obtained in our study show the existence changes in GSH content. The observed lower rates of GSH would rather have been resulted in GSH utilization or degradation. Moreover, increase of GSH content may be related to prevention of oxidative challenge [22]. Any stressful condition alters the biochemical composition. The change in metabolic rate leads towards the change in biochemical composition hence, the change in biochemical composition is an indicator of stress of chemical or physical nature in the surrounding, which mainly affects protein contents. Metal catalyzed formation of ROS capable of damaging proteins and lipids were well documented. It has been established that GSH content are related to the survival rate of mussels [23]. Although pollution influence on biochemical biomarker content is regulated by a feedback mechanism, the AchE levels can be used as a potential biomarker in green mussel. 
Acute toxicity of xenobiotics has traditionally been attributed to inhibition of Acetylcholinesterase (AChE) because the pathophysiological effects of these compounds are consistent with a cholinergic mechanism of toxicity. Xenobiotic compounds have direct toxic effects on other enzymes, acetylcholine receptors and are independent of AChE inhibition. AChE appears to be an important means to determine the biological effects of many neurotoxic contaminants in the aquatic habitats. Hence $\mathrm{AChE}$ is regarded as the reliable biomarker in the environmental pollution for monitoring programs. Marine bivalves such as snails, oysters and mussels were widely used as bioindicators of contamination in the monitoring of pollutant effects. As filter feeders, these species are known to be good general indicators of chemical contamination. The decrease in AChE activity in the oyster was efficiently used as a biomarker of exposure to neurotoxic compounds. Moreover, the kinetic and toxicological properties of AChE in bivalves have been extensively studied, allowing the optimization of the assays to measure AChE activity in different species, [24].

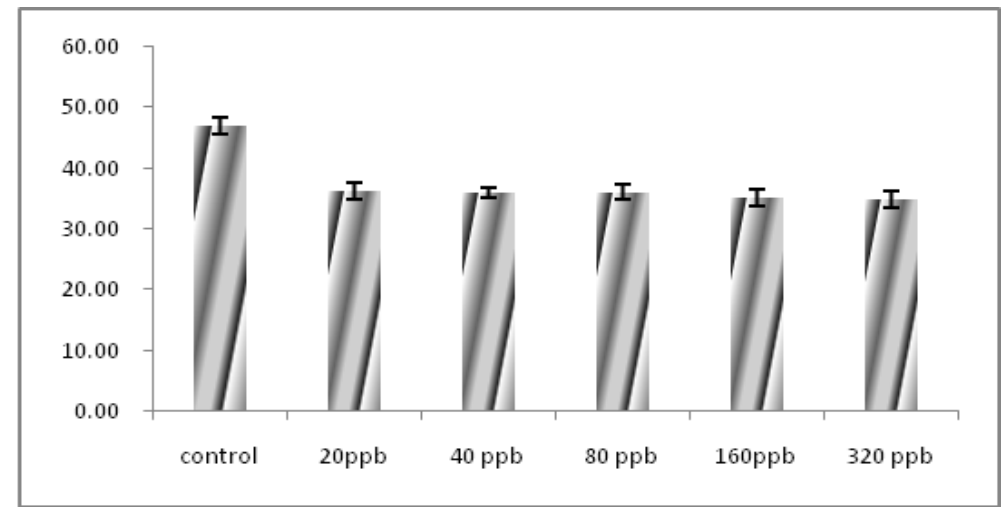

Fig. 1: Variation of protein in arsenic exposed Perna indicus in short-term chronic toxic test with concentrations in ' $\mathrm{X}$ ' axis (ppb= $\mu \mathrm{g} / \mathrm{l})$ and measured protein ( $\mathrm{mg}$ protein $/ \mathrm{g}$ tissue), represented as mean and standard deviation, with $\mathrm{n}=3$

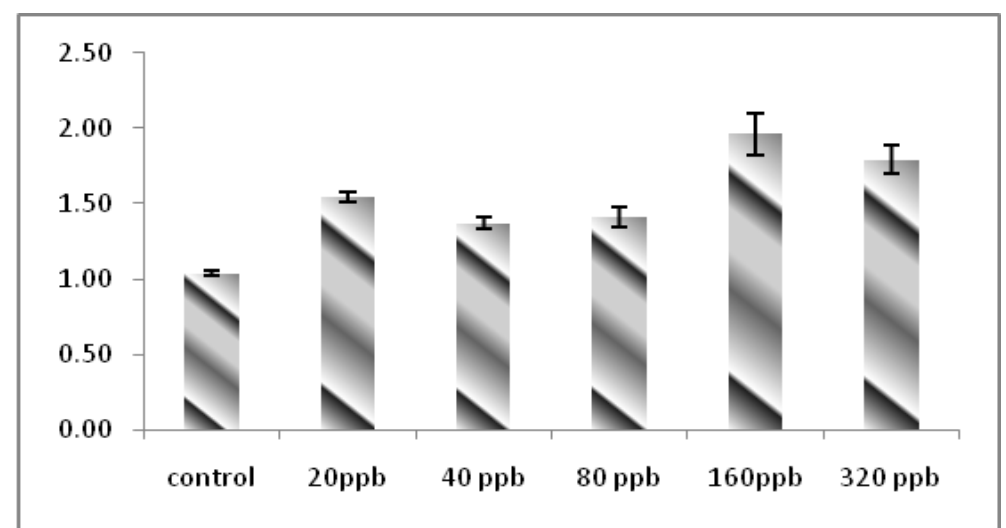

Fig. 2: Acetylcholinesterase (AChE) in arsenic exposed Perna indicus in short-term chronic toxic test with concentrations in ' $\mathrm{X}$ ' axis (ppb= $\mu \mathrm{g} / \mathrm{l})$ and measured $\mathrm{AChE}(\mathrm{nM} / \mathrm{min} / \mathrm{mg}$ protein), represented as mean and standard deviation, with $\mathrm{n}=3$

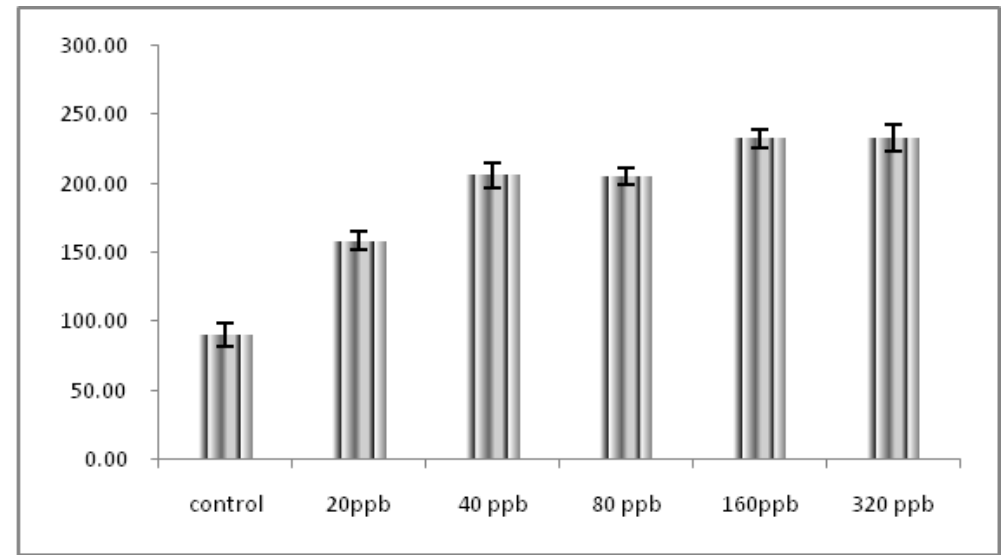

Fig. 3: Reduced glutathione (GSH) in arsenic exposed Perna indicus in short-term chronic toxic test with concentrations in ' $\mathrm{X}$ ' axis (ppb= $\mu \mathrm{g} / \mathrm{l})$ and measured GSH ( $\mu \mathrm{mol}$ of GSH oxidized / mg protein), represented as mean and standard deviation, with $\mathrm{n}=3$ 


\section{Conclusion}

Alterations in antioxidant enzyme activities and other biomarkers of oxidative stress in Perna indica may cause biochemical dysfunction. Our results indicate a significant elevation in lipid peroxidation, glutathione $S$-transferase, and acetylcholinesterase in P.indica. In addition, the results provide evidence that enzymic and non-enzymic biomarkers of oxidative stress can be sensitive indicators of aquatic pollution caused by heavy metals. The antioxidant defense system is being increasingly studied because of its potential utility to provide biochemical biomarkers that could be used in environmental monitoring system. In view of the state of pollution in marine environment it is indeed an urgent need of the hour to evaluate the ecotoxicological impact of various types of contaminants in the marine environment using molecular biomarkers

\section{References}

[1] M.V. Monferran, S.F. Pesce, J. Cazenave, D.A. Wunderlin, Detoxification and antioxidant responses in diverse organs of Jenynsia multidentata experimentally exposed to 1, 2- and 1, 4-dichlorobenzene, Environmental Toxicology, 23, (2008), 184-192

[2] L.R. Vieira, C. Gravato, A.M.V. Soares, F. Morgado L. Guilhermino, Acute effects of copper and mercury on the estuarine fish Pomatoschistus microps: Linking biomarkers to behaviour, Chemosphere, 76, (2009), 1416-1427

[3] T.J. Runnalls, D.N. Hala, J.P. Sumpter, Preliminary studies into the effects of the human pharmaceutical Clofibric acid on sperm parameters in adult Fathead minnow, Aquatic toxicology, 84, (2007), 111-118

[4] M. Faria, M.A. Lopez, M.F. Sanjuan, S. Lacorte, C. Barata, Comparative toxicity of single and combined mixtures of selected pollutants among larval stages of the native freshwater mussels (Unio elongatulus) and the invasive zebra mussel (Dreissena polymorpha), Science of the Total Environment, 408, (2010), 2452-2458

[5] D. Abele, S. Puntarulo, Formation of reactive species and induction of antioxidant defense systems in polar and temperate marine invertebrates and fish, Comparative Biochemistry and Physiology Part A: Molecular \& Integrative Physiology, 138, (2004), 405-415

[6] C. Gravato, M. Teles, M. Oliveira, M.A. Santos, Oxidative stress, liver biotransformation and genotoxic effects induced by copper in Anguilla anguilla L.-the influence of pre-exposure to bnaphthoflavone, Chemosphere, 65, (2006), 1821-1830

[7] M. Oliveira, I. Ahmad, V.L. Maria, M. Pacheco, M.A. Santos, Monitoring pollution of coastal lagoon using Liza aurata kidney oxidative stress and genetic endpoints: An integrated biomarker approach, Ecotoxicology, 19, (2010), 643-653

[8] R.J. Brown, S.D. Rundle, T.H. Hutchinson, T.D. Williams, M.B. Jones, A copepod life-cycle test and growth model for interpreting the effects of lindane, Aquatic Toxicology, 63, (2003), 1-11

[9] R. S. A. P. Dhivya, A. R. Lipton, M. Sarika, S. Aishwarya, G. Nair, Physiological responses of brown mussel (Perna Indica) towards alternations in marine temperature, Journal of Environmental Sciences, 1, (2011), 281-286

[10] E.M.S. Astorga, E. M. Rodriguez-Rodriguez, C. Diaz-Romero, Comparison of mineral and trace element concentrations in two mollusks form the Srait of Magellan (Chile), Journal of Food Composition and Analysis, 20(3-4), (2007), 273-279

[11] USEPA (United States Environmental Protection Agency), Understanding and Accounting for Method Variability in Whole Effluent Toxicity Applications under the National Pollutant Discharge Elimination System, EPA 833- R-00-003, (2002), http://www.toxicity.com/pdf/epa2000june.pdf

[12] S.R. Alves, C. Severino, P.C. Ibbotson, D.P. Silva, A.Z. Lopes, F.R.A.S. Saenz, L.A. Bainy, Effects of furadan in the brown mussel Perna perna and in the mangrove oyster Crassostrea rhizophorae, Marine Environmental Research, 54, (2011), 241-245

[13] M.S. Moron, J.W. Beperre, B. Wick, Levels of glutathione, glutathione reductase, glutathione-S transferase in rat lung and liver, Biochemica Biophysica Acta, 582, (1979), 67-78

[14] O.H. Lowry, N.J. Rosebrough, A.L. Farr, R.J. Randall, Protein measurement with the Folin phenol reagent, Journal of Biological Chemistry, 193, (1951), 265-275

[15] D.W. Filho, T. Tribess, C. Gaspari, F.D. Claudio, M.A. Torres and A.R.M. Magalhaes, Seasonal changes in antioxidant defences of the digestive gland of the brown mussel (Perna perna), Aquaculture, 203, (2001), 149-158

[16] I. Lima, S.M. Moreira, J.R. Osten, V.M. Soares, L. Guilhermino, Biochemical responses of the marine mussel Mytilus galloprovincialis to petrochemical environmental contamination along the North-western coast of Portugal, Chemosphere, 66, (2007), 1230-1242

[17] J.S.I. Rajkumar, M.C. John Milton, Biochemical changes induced by cadmium, copper, lead and zinc exposure to Perna viridis under longterm toxicity test. International Journal of Pharma and Biosciences, 2(3), (2011), 50-59

[18] W.H. Habig, , M.J. Papst, W.B. Jacoby, Glutathione S-transferase, the first step in mercapturic acid formation Journal of Biological Chemistry, 249, (1974), 7130-7139

[19] A. Naganuma, M.E. Anderson, A. Meister, Cellular glutathione as a determinant of sensitivity to mercuric chloride toxicity: Prevention of toxicity by giving glutathione monoester, Biochemical Pharmocology, 40, (1990), 693-697

[20] A.L. Dafre, I.D. Medeiros, I.C. Muller, E.C. Ventura, A.C.D Bainy, Antioxidant enzymes and thiol/disulfide status in the digestive gland of the brown mussel Perna perna exposed to lead and paraquat, Chemico-Biological Interactions, 149, (2004), 97-105

[21] M.J. Bebianno, R. Company, A. Serafim, R.P. Cosson and A.F. Medoni, Antioxidant systems and lipid peroxidation in Bathymodiolus azoricus from Mid-Atlantic Ridge hydrothermal vent fields, Aquatic Toxicology, 75, (2005), 354-373

[22] M. Radlowska, J. Pempkowiak, Stress-70 as indicator of heavy metals accumulation in blue mussel Mytilus edulis, Environment International, 27, (2002), 605-608

[23] G.L. Ellman, K.D. Courtney, V. Andres and R.M. Featherstone, A new and rapid colorimetric determination of acetylcholinesterase activity, Biochemical Pharmacology, 7, (1961), 88-95

[24] M. Brown, I.M. Davies, C.F. Moffat, J. Redshaw, J.A. Craft, Characterization of choline esterases and their tissue and subcellular distribution in mussel (Mytilus edulis), Marine Environmental Research, 57, (2004), 155-169 